\title{
Termiticidal activity of oil from Jatropha curcas L. and Azadirachta indica A. Juss against Coptotermes sjostedti Holmgren (Isoptera: Rhinotermitidae)
}

\author{
Simon Idoko Okweche ${ }^{1 *}\left(\mathbb{D}\right.$, Patrick Matthew Hilili ${ }^{1}$ and Edache Ernest Ekoja ${ }^{2}$
}

\begin{abstract}
Background: Coptotermes sjostedti Holmgren (Isoptera:Rhinotermitidae) is one of the major termite species found infesting woods and other plant materials in Africa. Bioassays were carried out at the Arboretum of the Department of Forestry and Wildlife Resources Management, University of Calabar, Nigeria to investigate the effect of oils from the kernel of Jatropha curcas L. and Azadirachta indica oils A. Juss against the African subterranean termite (Coptotermes sjostedti Holmgren). Treatments comprised of the plant oils and Solignum (a synthetic termiticide, serving as positive control) applied at the rate of 5,10 and $15 \mathrm{~mL}$ per $100 \mathrm{~cm}^{3}$ of the wood from seven plant species. Untreated woods also served as control. Seven wood species were placed in a test arena and artificially infested with 50 termites per unit. The setup was a randomized complete block design with four replicates. Data on termite mortality and wood weight loss were recorded.
\end{abstract}

Results: The use of 10 and $15 \mathrm{~mL}$ of J. curcas oil caused more than $90 \%$ mortality of C. sjostedti, after $96 \mathrm{~h}$, kept wood consumption by the insect below $6.0 \%$ after 3 months, and these outcomes were similar to that of Solignum at the same concentrations. About 35.0-65.2\% reduction in weight was observed among untreated woods from the tested woods, indicating their susceptibility to C. sjostedti attacks. Correlation analysis shows a significant $(r>-0.900$; $P<0.0001)$ negative association between termite mortality and the rate of wood consumption.

Conclusion: The use of $J$. curcas oil at $10 \mathrm{~mL}$ per $100 \mathrm{~cm}^{3}$ of wood could be a potent alternative to Solignum for the control of C. sjostedti.

Keywords: Termiticide, Jatropha curcas, Azadirachta indica solignum, Wood consumption, Termite mortality

\section{Background}

Termites are eusocial insects that belong to the order Isoptera in the animal kingdom. They demonstrate group integration, division of labour among caste [viz: the fertile (reproductives) and the sterile (workers, pre-soldiers and soldiers], and their population could grow drastically with several overlapping of generations (Myles 1998;

\footnotetext{
${ }^{*}$ Correspondence: idokosi@unical.edu.ng

1 Department of Forestry and Wildlife Resources Management, University of Calabar, P.M.B. 1115, Calabar, Nigeria

Full list of author information is available at the end of the article
}

Osipitan et al. 2010; Watanabe et al. 2014). The insect exhibits hemimetabolism which is characterized by a gradual development of individuals from the egg, through several moults of the nymphs and into one of the adult castes (Kuriachan and Gold 1998; Osipitan et al. 2010). Termites are ubiquitous, and they have gained the reputation of being among the most successful groups of insects found in tropical, subtropical, and warm temperate regions of the world. They play significant roles in the world's ecosystem by accelerating plant product decomposition, reclamation of damaged soil, contributing to atmospheric gases (such as carbon dioxide and methane), 
redistribution of minerals, fatty acids, vitamins, amino acids, etc. (Odelson and Breznak 1983; Guo et al. 1991; Abe et al. 2000).

The African subterranean termite, Coptotermes sjostedti Holmgren 1911 (Isoptera: Rhinotermitidae) is one of the major damaging species found in Nigeria, Cameroon, Democratic Republic of Congo, Gambia, Ghana, Guinea, Ivory Coast, Mozambique, Senegal, Angola, Sierra Leone, Somalia, Sudan, São Tomé and Príncipe, Tanzania and Uganda (Harris 1966; Ndiaye et al. 2019). They have been reported to thrive in other tropical biogeographical regions of the world as well (Chouvenc et al. 2016). The arthropod feeds mainly on living or dead trees tissues, but oftentimes, they also damage parts of arable crops by their networks of shelter and forage tubes. Like many termite species, their presence is usually indicated by earthcovered runways or tubes found on the external surfaces of trees and other targets (CABI Datasheet 2019). Generally, the genus Coptotermes is considered as the most aggressive subterranean termite, and the global damage they cause was estimated at US \$ 22 billion to US \$ 40 billion worldwide (Su 2002; Rust and Su 2012; Kuswanto et al. 2015).

Woods are a widely available and relatively inexpensive natural resource in most tropical and sub-tropical regions of the world. When harvested from plants and processed, woods are subjected to a variety of uses due to their low electrical/thermal conductivity, workability, beauty, density, strength, etc. (Ross 2010). Besides, wood from many plant species has been used for centuries as fuel and as a construction material for houses, furniture, bridges, etc. (Briffa 2008). Unfortunately, woods are susceptible to attack by insects, bacteria, fungi, marine worms, and if left unprotected in some landscapes, they could deteriorate over time (Samuel 2004). Attacks by termites remain the most serious threat to wood structures, forest trees and crops (such as yam and cassava, sugar cane, groundnuts, sorghum, maize, etc.) in tropical and subtropical countries (Johnson and Wood, 1980; Logan et al. 1990; Osipitan and Oseyemi 2012).

For decades, man has relied on soil and wood treatment with termiticides such as like chlorpyrifos, bifenthrin, chlorfenapyr, permethrin, cypermethrin, imidacloprid, and fipronil as conventional tools for the control of termites (Su and Scheffrahn 1990; Femi-ola et al. 2008). But these chemical pesticides are usually expensive, hazardous for the environment and human exposure could create adverse health problems. There are also shreds of evidence indicating that many insect pests develop resistance to synthetic chemicals as a result of their repeated/ injudicious use (Padi et al. 1999). Currently, research efforts have been directed at the search for a safe and ecofriendly alternative to synthetic chemicals used for the control of termites. Extracts, latex and quinones of many plant species have been tested against termites (Ganapaty et al. 2004; Upadhyay 2013). Ahmed and Girma (2013) investigated the efficacy of extracts from Azadirachta indica A. Juss, Croton macrostachyus Hochst. ex Delile, Tagetes minuta Linn. and Datura stramonium Linn. against Odontotermes obesus Rambur. Ipomea carnea Jacq. Cleome viscose Linn. and Pavonia glechomifolia A. Rich. were also tested against Microcerotermes beesoni Snyder (Singha et al. 2012). Their results suggested that plant-based products could play a significant role in the control of termites. But it is yet to be known if some important wood species like Antiaria toxicera Lesch., Gmelina arborea Roxb., Parkia biglobosa Jacq., Pycnanhus angolensis (Welw.) Warb, Terminalia superba Engl. \& Diels, Ceiba pentandra (L.) Gaertn. and Baphia nitida Lodd will receive adequate protection from $C$. sjostedti attacks using biologically active oil extracts from Azadirachta indica A. Juss and Jatropha curcas L.

The growing global demand for botanical termiticides has made it imperative for research to be directed at the development of potent alternatives to Solignum, a well-known synthetic termiticide used for the control of many termite species. Generally, termiticides from plant sources are known to be safe for both man and the environment, exhibits broad insecticidal activity, demonstrates relatively specific mode of action, and their preparation/application methods are easier compared with synthetic chemicals (Addisu et al. 2014).

We therefore setup this experiment to test the toxicity of different concentrations of oil extracts from the kernels of $A$. indica and J. curcas against $C$. sjostedti using some wood species that are commonly found in Africa.

\section{Methods}

\section{Study area}

The experiment was carried out at the Arboretum of the Department of Forestry and Wildlife Resources Management, University of Calabar, Cross River State, Nigeria. The State lies within the rainforest zone of Nigeria (coordinates: Latitude $4^{\circ} 34^{\prime} 59.99^{\prime \prime} \mathrm{N}$ and Longitude $8^{\circ} 24^{\prime} 59.99^{\prime \prime}$ E). The weather is characterized by a pattern of alternating wet and dry seasons. The period of rains is from April to September while the dry spell is from October to March.

\section{Preparation of plant oil extracts}

Oil from the kernels of $A$. indica and $J$. curcas were used for the experiment (Table 1). Matured ripe seeds were collected from the plant species found within University of Calabar, Cross River State, Nigeria. They were de-husked, de-shelled, and the kernels were sun-dried for one week. Oil was extracted from the kernels using a 
Table 1 Plants evaluated for termiticidal activities against Coptotermes sjostedti (Isoptera: Rhinotermitidae)

\begin{tabular}{lllll}
\hline Common name & Scientific name & Family & Sub-family & Product used \\
\hline Neem & Azadirachta indica A. Juss & Meliaceae & Melioideae & Kernel oil \\
Jatropha & Jatropha curcas Linn & Euphorbiaceae & Acalyphoideae & Kernel oil \\
\hline
\end{tabular}

Soxhlet apparatus at the Department of Chemistry, University of Calabar, Nigeria. Petroleum ether 60/80 was the solvent used for the extraction. The oil extract was kept in a sterilized round-bottom flask and stored in a refrigerator $\left(4{ }^{\circ} \mathrm{C}\right)$ until it was used for the experiment.

\section{Preparation of wood samples}

Antiaria toxicera Lesch., Gmelina arborea Roxb., Parkia biglobosa Jacq., Pycnanhus angolensis (Welw.) Warb, Terminalia superba Engl. \& Diels, Ceiba pentandra (L.) Gaertn. and Baphia nitida Lodd at the Marian Forest Reserve, Calabar were identified. Wood samples obtained from these plant species were processed at the Marian Timber Market, Calabar. The samples were cut into $10 \mathrm{~cm} \times 5 \mathrm{~cm} \times 2 \mathrm{~cm}$ dimension using a saw and sundried for one week before the experiment.

\section{Termites identification and collection}

Workers of the African subterranean termites (Coptotermes sjostedti Holmgren) were used for the experiment. The termite colony was found on Kapok tree (Ceiba pentandra (L.) Gaertn) at the Arboretum of the Department of Forestry and Wildlife Resources Management, University of Calabar, Cross River State, Nigeria. Another termite colony was maintained at the Soil Science Research Laboratory of the University of Calabar, Nigeria. The termites were identified under a microscope, using the identification protocol described by Harris (1996) and Scheffrahn et al. (2004). The identification criteria considered were the size of termites head, mandible, body and number of antennal articles.

\section{Experimental treatments and design}

The setup was in a randomized complete block design with four replicates. Treatments comprised of $A$. indica and $J$. curcas kernel oils along with Solignum (as positive control) applied at the rate of 5.0, 10.0 and $15 \mathrm{~mL} /$ $100 \mathrm{~cm}^{3}$ of the selected wood. Untreated wood from each of the selected plant species also served as control. A modified soil barrier test method was used for the assay. The test arena comprised of trenches of about $20 \mathrm{~cm} \times 20 \mathrm{~cm} \times 20 \mathrm{~cm}$ dimension with the base having about 2-cm thick layer of moistened autoclaved soil. Different concentrations of the termiticides were applied on the woods samples and placed at the base of the test arena. The top portion was covered with 1-mm iron mesh net to prevent the escape of the insects. About 50 workers of C. sjostedti were introduced to each unit, and they were allowed to feed on the wood species while termite mortality data were recorded at $12 \mathrm{~h}$ intervals until $96 \mathrm{~h}$ after exposure. The percentage termite mortality was calculated using:

$$
\text { Mortality }(\%)=\frac{\text { Number of dead termites } \times 100}{\text { Total number of termites }}
$$

At 12 weeks after treatment, the remaining wood samples were cleaned, sun-dried for $24 \mathrm{~h}$ and the weight loss (WL) caused by the feeding activities of $C$. sjostedti was calculated using the formula below:

$$
\% \mathrm{WL}=[(\mathrm{Wi}-\mathrm{Wf}) / \mathrm{Wi}] \times 100 .
$$

where Wi and Wf are the initial and final weight of wood, respectively.

\section{Data analyses}

Data on mortality were normalized using arcsine transformation before subjecting them to analysis of variance (ANOVA). All data collected were subjected to ANOVA using of SAS (2009) software. Mean values were separated using Duncan New Multiple Range Test (DNMRT) at $5 \%$ level of significance. Pearson's correlation analysis was also carried out to show the strength of association between termite mortality and wood weight loss.

\section{Results}

A dose-dependent effect of the plant oils and Solignum were observed on adult C. sjostedti, mortality across the $96 \mathrm{~h}$ of mortality assessment (Table 2). The number of termites killed after contact with $15 \mathrm{~mL}$ of the tested termiticides was the highest, and it was significantly $(P<0.0001)$ different from mortality recorded in the control and on woods treated with 5 and $10 \mathrm{~mL}$ of the botanical oils and Solignum. J. curcas seed oil appeared to be more toxic to $C$. sjostedti compared with $A$. indica oil. The use of $15 \mathrm{~mL}$ of the synthetic chemical (Solignum) brought about the highest $C$. sjostedti mortality, but it was not different $(P>0.05)$ from the mortality caused by $15 \mathrm{~mL}$ of $J$. curcas throughout the $96 \mathrm{~h}$ period, except at $12 \mathrm{~h}$ after exposure. At $96 \mathrm{~h}$ after exposure, the use of 10 and $15 \mathrm{~mL}$ of $J$. curcas oil brought about $100 \%$ C. sjostedti 
Table 2 Lethal effects of different concentration of A. indica, J. curcas and Solignum on Coptotermes sjostedti (Isoptera: Rhinotermitidae) at different time of exposure on wood from Ceiba pentandra (L.) Gaertn

\begin{tabular}{|c|c|c|c|c|c|c|c|c|c|}
\hline \multirow[t]{2}{*}{ Termiticide } & \multirow[t]{2}{*}{ Conc } & \multicolumn{8}{|c|}{ Time of exposure (h) } \\
\hline & & 12 & 24 & 36 & 48 & 60 & 72 & 84 & 96 \\
\hline \multirow[t]{3}{*}{ A. indica } & 5 & $8.77 \pm 0.40 \mathrm{e}$ & $13.38 \pm 0.67 d$ & $17.01 \pm 0.60 f$ & $21.33 \pm 0.88 f$ & $26.62 \pm 0.87 f$ & $33.00 \pm 0.92 f$ & $38.30 \pm 0.95 e$ & $43.91 \pm 0.71 \mathrm{e}$ \\
\hline & 10 & $13.61 \pm 0.64 d$ & $19.57 \pm 1.72 b$ & $25.18 \pm 1.09 e$ & $32.83 \pm 0.77 e$ & $39.56 \pm 0.85 e$ & $48.87 \pm 2.31 \mathrm{e}$ & $54.08 \pm 1.25 d$ & $62.84 \pm 1.62 d$ \\
\hline & 15 & $16.83 \pm 0.60 c$ & $22.77 \pm 0.87 c$ & $28.38 \pm 0.92 d$ & $36.03 \pm 0.64 d$ & $42.76 \pm 0.88 \mathrm{de}$ & $52.07 \pm 0.71 d$ & $72.28 \pm 1.03 c$ & $80.04 \pm 1.12 c$ \\
\hline \multirow[t]{3}{*}{ J. curcas } & 5 & $12.40 \pm 0.75 d$ & $19.55 \pm 1.90 c$ & $25.49 \pm 1.07 e$ & $48.52 \pm 1.89 c$ & $59.62 \pm 0.99 c$ & $66.00 \pm 0.91 \mathrm{~cd}$ & $76.86 \pm 1.88 c$ & $80.76 \pm 1.06 c$ \\
\hline & 10 & $18.14 \pm 1.51 b$ & $30.03 \pm 1.20 b$ & $35.00 \pm 1.40 c$ & $61.62 \pm 1.52 b$ & $73.29 \pm 0.96 b$ & $79.95 \pm 0.96 b$ & $83.38 \pm 2.23 b$ & $100.00 \pm 0.00 a$ \\
\hline & 15 & $19.88 \pm 0.93 b$ & $34.77 \pm 0.93 a$ & $54.74 \pm 2.21 \mathrm{ab}$ & $65.36 \pm 1.11 a$ & $76.03 \pm 0.97 a$ & $85.69 \pm 1.01 a$ & $89.12 \pm 1.13 a$ & $100.00 \pm 0.00 a$ \\
\hline \multirow[t]{3}{*}{ Solignum } & 5 & $13.78 \pm 0.90 \mathrm{~d}$ & $22.10 \pm 0.78 c$ & $38.62 \pm 2.48 c$ & $50.91 \pm 2.45 c$ & $60.52 \pm 1.66 c$ & $71.19 \pm 1.72 \mathrm{c}$ & $77.81 \pm 1.30 c$ & $85.91 \pm 1.31 b$ \\
\hline & 10 & $19.08 \pm 1.25 b$ & $33.49 \pm 2.12 \mathrm{ab}$ & $50.95 \pm 1.79 b$ & $60.67 \pm 0.97 b$ & $72.29 \pm 1.20 b$ & $80.57 \pm 0.77 b$ & $85.76 \pm 0.87 b$ & $100.00 \pm 0.00 a$ \\
\hline & 15 & $24.18 \pm 2.97 a$ & $35.69 \pm 1.13 a$ & $57.15 \pm 0.73 a$ & $66.87 \pm 0.97 a$ & $77.49 \pm 1.05 a$ & $86.77 \pm 0.87 a$ & $100.00 \pm 0.07 a$ & $100.00 \pm 0.00 \mathrm{a}$ \\
\hline Control & 0 & $0.00 \pm 0.00 f$ & $0.00 \pm 0.00 \mathrm{e}$ & $0.00 \pm 0.00 \mathrm{~g}$ & $0.00 \pm 0.00 \mathrm{~g}$ & $0.00 \pm 0.00 \mathrm{~g}$ & $0.00 \pm 0.00 \mathrm{~g}$ & $0.00 \pm 0.00 f$ & $0.00 \pm 0.00 f$ \\
\hline$P$ & & $<0.0001$ & $<0.0001$ & $<0.0001$ & $<0.0001$ & $<0.0001$ & $<0.0001$ & $<0.0001$ & $<0.0001$ \\
\hline
\end{tabular}

Data (\%) were transformed (arcsine) before the analysis of variance; Means ( \pm Standard error) are values of four replicates; Means with the same lower case alphabet in a column are not significantly different from each other (DNMRT: $P>0.05) ;{ }^{b}$ concentration ( $\mathrm{mL} / 100 \mathrm{~m}^{3}$ of wood surface); $P=$ Probability value

mortality, and it was similar to the mortality caused by 10 and $15 \mathrm{~mL}$ of Solignum.

The mortality levels described by the probit models for each termiticides tested showed low $X^{2}$-values and high $P$-values over the 4 days of exposure (Table 3 ). Among the two plant oils, $J$. curcas had a lower $\mathrm{LC}_{50}$ value $(138.70,36.08,14.29,5.30,2.75,2.50,0.95$ and $0.05 \mathrm{~mL}$ at $12,24,36,48,60,72,84$ and $96 \mathrm{~h}$ after exposure, respectively) compared with $A$. indica $(215.78,138.70,72.45$, $33.66,21.59,12.26,7.70$ and $6.19 \mathrm{~mL}$ at $12,24,36,48,60$, 72,84 and $96 \mathrm{~h}$ after exposure, respectively). The slope of the probit models also shows that the termiticidal activity was more rapid in J. curcas than in A. indica.

The dose-dependent mortality trend of the botanical oils was also sustained when used against $C$. sjostedti in all the wood species evaluated (Table 4). C. sjostedti mortality increased as the concentration of the tested termiticides increases. More $C$. sjostedti were killed by the use of $J$. curcas oil than $A$. indica oil. Irrespective of wood species, the use of 10 and $15 \mathrm{~mL}$ of $J$. curcas oil brought about $\geq 90 \%$ mortality of $C$. sjostedti mortality, but it was not significantly $(P>0.05)$ different from the mortality caused by the same concentrations of Solignum.

All the wood species tested in the study appear to be susceptible to damage induced by $C$. sjostedti. However, the rate of damage caused by the feeding activities of the insect varied among the wood species (Table 5). About $35.0-65.2 \%$ reduction in wood weight was observed among untreated wood from different plants species, and it was significantly $(P<0.0001)$ higher compared with the weight loss in treated woods. The use of $15 \mathrm{~mL}$ of Solignum brought about the lowest loss in weight of all the woods tested, but it was not significantly $(P>0.05)$ different from the loss that occurred when 10 and $15 \mathrm{~mL}$ of $J$. curcas and $10 \mathrm{~mL}$ of Solignum was used. There were strong negative correlations between percentage termite mortality and percentage loss in wood weight $(r>-0.900 ; P<0.0001)$ (Table 6).

\section{Discussion}

The study shows that infestation by $C$. sjostedti could induce serious damage on susceptible plant materials if preventive or curative measures are not employed as mentioned in previous studies by (Harris 1966; Johnson and wood 1980; Scheffrahn et al. 2004; Loko et al. 2019). The two plant oils (J. curcas and A. indica) evaluated in this study showed significant termiticidal activity against C. sjostedti. However, the oil extract of J. curcas kernel seems to be the most potent when compared with that of $A$. indica. Both C. sjostedti mortality and wood weight loss results from 10 and $15 \mathrm{~mL}$ of $J$. curcas were not different from that of the synthetic chemical, Solignum. This outcome conforms to the reports of Goktas et al. (2007) and Okweche et al. (2015) who observed the effectiveness of some plant oils in preventing decay and enhancing the resistance of some wood species to withstand attack by some pests and diseases. All the concentrations of J. curcas oil tested was able to increase $C$. sjostedti mortality significantly within $96 \mathrm{~h}$, and provided better protection against wood consumption by the insect when compared with oil from $A$. indica kernel. The use of plant extracts have also been reported by several authors to be effective in the management of termite and could serve as an alternative to synthetic insecticides (Sen 2001; Sbeghen et al. 2002; Sohail et al. 2005; Abdullah et al. 2014; Ekhuemelo and Musa 2015). Furthermore, the non-significant 
Table 3 Lethal concentration $\left(\mathrm{LC}_{50}\right)$ of $A$. indica, J. curcas, and Solignum on adult Coptotermes sjostedti (Isoptera: Rhinotermitidae)

\begin{tabular}{|c|c|c|c|c|c|}
\hline Time (h) & Termiticide & Slope \pm SE & $\mathrm{LC}_{50}(95 \% \mathrm{FL})$ & $x^{2}$ & $P$ \\
\hline \multirow[t]{3}{*}{12} & A. indica & $0.66 \pm 0.32$ & $\begin{array}{c}215.78(52.40- \\
1.43 \mathrm{E}+08)\end{array}$ & 0.05 & 0.951 \\
\hline & J. curcas & $0.83 \pm 0.34$ & $\begin{array}{c}138.70(41.12- \\
4.80 E+06)\end{array}$ & 0.03 & 0.855 \\
\hline & Solignum & $0.81 \pm 0.38$ & $\begin{array}{c}113.23(38.23- \\
1.60 \mathrm{E}+05)\end{array}$ & 0.06 & 0.808 \\
\hline \multirow[t]{3}{*}{24} & A. indica & $0.76 \pm 0.31$ & $\begin{array}{c}138.70(41.17- \\
4.81 \mathrm{E}+06)\end{array}$ & 0.03 & 0.855 \\
\hline & J. curcas & $0.99 \pm 0.28$ & $36.08(21.36-416.45)$ & 0.12 & 0.729 \\
\hline & Solignum & $0.87 \pm 0.28$ & $36.23(20.51-383.22)$ & 0.61 & 0.436 \\
\hline \multirow[t]{3}{*}{36} & A. indica & $0.81 \pm 0.29$ & $\begin{array}{r}72.45(30.08- \\
1.08 \mathrm{E}+04)\end{array}$ & 0.14 & 0.714 \\
\hline & J. curcas & $1.58 \pm 0.27$ & $14.29(12.01-18.96)$ & 3.70 & 0.554 \\
\hline & Solignum & $0.99 \pm 0.26$ & $9.71(7.52-13.12)$ & 0.02 & 0.878 \\
\hline \multirow[t]{3}{*}{48} & A. indica & $0.94 \pm 0.28$ & $33.66(20.08-215.62)$ & 0.43 & 0.514 \\
\hline & J. curcas & $0.93 \pm 0.26$ & $5.30(2.49-7.05)$ & 0.29 & 0.592 \\
\hline & Solignum & $0.86 \pm 0.26$ & $4.74(1.67-6.59)$ & 0.01 & 0.908 \\
\hline \multirow[t]{3}{*}{60} & A. indica & $0.95 \pm 0.27$ & $21.59(14.98-67.01)$ & 0.53 & 0.468 \\
\hline & J. curcas & $1.01 \pm 0.27$ & $2.75(0.72-4.31)$ & 0.52 & 0.469 \\
\hline & Solignum & $1.03 \pm 0.27$ & $2.73(0.74-4.26)$ & 0.02 & 0.888 \\
\hline \multirow[t]{3}{*}{72} & A. indica & $1.06 \pm 0.27$ & $12.26(9.82-18.30)$ & 0.85 & 0.358 \\
\hline & J. curcas & $1.38 \pm 0.29$ & $2.50(1.03-3.70)$ & 0.01 & 0.908 \\
\hline & Solignum & $1.14 \pm 0.30$ & $1.65(0.290-2.96)$ & 0.14 & 0.709 \\
\hline \multirow[t]{3}{*}{84} & A. indica & $1.79 \pm 0.27$ & $7.70(6.55-8.79)$ & 2.06 & 0.151 \\
\hline & J. curcas & $1.00 \pm 0.31$ & $0.95(0.03-2.24)$ & 0.35 & 0.552 \\
\hline & Solignum & $1.06 \pm 0.32$ & $0.96(0.05-2.20)$ & 0.02 & 0.884 \\
\hline \multirow[t]{3}{*}{96} & A. indica & $1.01 \pm 0.27$ & $6.19(5.13-7.07)$ & 1.64 & 0.200 \\
\hline & J. curcas & $0.35 \pm 0.29$ & $0.05(0.01-1.71)$ & 0.15 & 0.697 \\
\hline & Solignum & $0.26 \pm 0.29$ & $0.02(0.00-0.04)$ & 0.13 & 0.721 \\
\hline
\end{tabular}

$N=50$ termites; $\mathrm{SE}$, standard error; $\mathrm{LC}$ : Lethal concentration $\left(\mathrm{mLkg}^{-1}\right)$; $\mathrm{FL}$, Fiducial limits; $X^{2}$, Chi-square value, $P$, Probability value; $h$, hours

chi-square values for both $J$. curcas and $A$. indica oils shows that toxicity models generated from the probit regression were similar to the theoretical models which described the observed mortality of $C$. sjostedti on treated wood samples as an outcome of the toxic effect of the botanical oil extracts (Finney 1971).

Jatropha plant has been reported to contain several toxic metabolites such as sterols and terpene alcohols which are known to possess insecticidal properties (Adolf et al. 1984). Oskoueian et al. (2011) reported the presence of gallic acid and pyrogallol (phenolics), rutin and myricetin (flavonoids) and daidzein (isoflavonoid) and phorbol esters in extract extracts from the kernel of J. curcas. The GC-MS analysis conducted in their study also identified 2-(hydroxymethyl)-2 nitro$1, \beta$-sitosterol, 3-propanediol, 2-furancarboxaldehyde, 5-(hydroxymethy) and acetic acid in extracts from the kernel. The phorbol esters (tetra-cyclic diterpenes) fraction in J. curcas kernel oil was reported to exhibit insecticidal activity against some insect pests (Ratnadass and Wink 2012). About $40 \%$ of neem kernel is made up of oil, and azadirachtin was reported as the major bioactive component of this oil (Isman et al. 1991).

The mode of action of J. curcas kernel oil on insects has been described in some studies. The oil has been reported to exhibit contact toxicity (Wink et al. 1997; Ratnadass et al. 2009; Li et al. 2004; Devappa et al. 2012), feeding deterrence (Ratnadass et al. 1997; Devappa et al. 2012; Li et al. 2004), anti-oviposition/ovicidal effects (Adebowale and Adedire, 2006; Agboka et al. 2009; Ratnadass et al. 2009; Kshirsagar, 2010; Nabil and Yasser 2012), repellency (Boateng and Kusi, 2008), insect growth regulatory effect (Singh and Sushilkumar, 2008; Wink et al. 1997; Sauerwein et al. 1993; Ratnadass et al. 2009), and reduction in amylase/lactic acid dehydrogenase activities (Dowlathabad et al. 2010) against many insect species. A combination of these properties may have influenced C. sjostedti mortality and the reduction in wood-feeding damage that was induced by J. curcas oil. Also, the azadirachtin component of neem oil has been reported to exhibit toxicity, long-term repellency, and feeding deterrent activity towards a species in Coptotermes genus (Isman et al. 1991; Grace and Yates, 2008).

Woods are known to differ in their susceptibility to termite attack; these differences may be attributed to factors such as chemical composition, wood density and availability of susceptible species (Jambere et al. 1995; Gérard et al. 2019). However, all the woods tested showed significant susceptibility to $C$. sjostedti attacks. Particularly, the untreated wood samples from all the tested plant species recorded the highest weight loss when compared with the treated samples, and it indicates high susceptibility of the wood species to C. sjostedti attacks. Termites are polyphagous in nature and could thrive on a wide range of economically important crops, forestry, rangelands, houses and other wooden structures (Debelo, 2020). Based on the results, wood consumption by C. sjostedti seems to be higher in Ceiba pentandra wood than other wood types tested. This result agrees with the report of Faruwa et al. (2015) who observed a significant impact of bio-based preservatives as control measures against damage caused by fungi and termite in Triplochiton scleroxylon, Gmelina arborea, Ceiba pentandra wood samples.

The significant negative association between termite mortality and wood weight loss further shows that the toxicity of the termiticides may be responsible for the significant reduction in termite wood consumption 
Table 4 Termiticidal efficacy of A. indica, J. curcas, and Solignum on Coptotermes sjostedti (Isoptera: Rhinotermitidae) in seven wood species

\begin{tabular}{|c|c|c|c|c|c|c|c|c|}
\hline \multirow[t]{2}{*}{ Termiticide } & \multirow[t]{2}{*}{ Conc } & \multicolumn{7}{|c|}{ Termite mortality at $96 \mathrm{~h}$ after exposure (\%) } \\
\hline & & AT & GA & BN & PB & PA & TS & $\mathrm{CP}$ \\
\hline \multirow[t]{3}{*}{ A. indica } & 5 & $41.60 \pm 1.20 f$ & $47.33 \pm 3.45 d$ & $47.00 \pm 0.58 d$ & $43.00 \pm 1.53 d$ & $40.00 \pm 1.16 \mathrm{e}$ & $43.33 \pm 0.88 \mathrm{e}$ & $43.91 \pm 0.71 \mathrm{e}$ \\
\hline & 10 & $70.62 \pm 1.76 \mathrm{e}$ & $50.59 \pm 1.60 d$ & $67.10 \pm 1.49 c$ & $55.00 \pm 2.89 c$ & $64.17 \pm 0.46 d$ & $67.67 \pm 1.45 d$ & $62.84 \pm 1.62 d$ \\
\hline & 15 & $72.60 \pm 3.70 d$ & $55.00 \pm 2.89 c$ & $68.33 \pm 1.67 c$ & $58.33 \pm 0.41 c$ & $66.33 \pm 1.86 c$ & $71.67 \pm 4.41 \mathrm{~cd}$ & $80.04 \pm 1.12 c$ \\
\hline \multirow[t]{3}{*}{ J. curcas } & 5 & $82.64 \pm 3.70 c$ & $87.67 \pm 1.45 b$ & $82.33 \pm 2.45 b$ & $81.67 \pm 2.03 c$ & $82.67 \pm 3.46 b c$ & $75.00 \pm 2.89 c$ & $80.76 \pm 1.06 c$ \\
\hline & 10 & $93.00 \pm 5.16 \mathrm{ab}$ & $90.00 \pm 4.15 a b$ & $90.30 \pm 3.15 \mathrm{ab}$ & $92.00 \pm 1.15 \mathrm{ab}$ & $95.00 \pm 1.16 a$ & $90.00 \pm 2.70 a b$ & $100.00 \pm 0.00 a$ \\
\hline & 15 & $95.30 \pm 3.30 \mathrm{ab}$ & $92.67 \pm 3.72 \mathrm{ab}$ & $95.33 \pm 2.67 a$ & $94.00 \pm 3.15 a$ & $96.00 \pm 0.56 a$ & $94.33 \pm 2.96 a$ & $100.00 \pm 0.00 \mathrm{a}$ \\
\hline \multirow[t]{3}{*}{ Solignum } & 5 & $90.00 \pm 1.15 b$ & $90.33 \pm 3.67 a b$ & $90.30 \pm 3.15 \mathrm{ab}$ & $88.33 \pm 1.67 b$ & $88.33 \pm 1.67 b$ & $86.67 \pm 2.67 b$ & $85.91 \pm 1.31 b$ \\
\hline & 10 & $97.30 \pm 2.67 a$ & $96.33 \pm 3.18 \mathrm{a}$ & $96.67 \pm 2.33 \mathrm{a}$ & $95.50 \pm 2.68 \mathrm{a}$ & $94.00 \pm 3.05 a$ & $91.33 \pm 4.09 a b$ & $100.00 \pm 0.00 \mathrm{a}$ \\
\hline & 15 & $98.50 \pm 0.00 \mathrm{a}$ & $98.80 \pm 1.00 \mathrm{a}$ & $97.00 \pm 2.40 \mathrm{a}$ & $98.30 \pm 0.86 a$ & $98.60 \pm 1.20 a$ & $96.67 \pm 1.33 a$ & $100.00 \pm 0.00 a$ \\
\hline Control & 0 & $0.00 \pm 0.00 \mathrm{~g}$ & $0.00 \pm 0.00 \mathrm{e}$ & $0.00 \pm 0.00 \mathrm{e}$ & $0.00 \pm 0.00 \mathrm{e}$ & $0.00 \pm 0.00 f$ & $0.00 \pm 0.00 f$ & $0.00 \pm 0.00 f$ \\
\hline$P$ & & $<0.0001$ & $<0.0001$ & $<0.0001$ & $<0.0001$ & $<0.0001$ & $<0.0001$ & $<0.0001$ \\
\hline
\end{tabular}

AT, Antiaria toxicera; GA, Gmelina arborea; BN, Baphia nitida; PB, Parkia biglobosa; PA, Pycnanhus angolensis; TS, Terminalia superba; CP, Ceiba pentandra; Data (\%) were transformed (arcsine) before the analysis of variance; Means ( \pm Standard error) are values of four replicates; Means with the same lower case alphabet

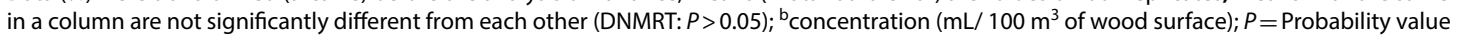

Table 5 Termite-induced weight loss in wood from seven plant species treated $A$. indica, J. curcas, and Solignum

\begin{tabular}{|c|c|c|c|c|c|c|c|c|}
\hline \multirow[t]{2}{*}{ Termiticide } & \multirow[t]{2}{*}{ Conc } & \multicolumn{7}{|c|}{ Weight loss (\%) } \\
\hline & & AT & $\mathrm{GA}$ & $\mathrm{BN}$ & PB & PA & TS & $\mathrm{CP}$ \\
\hline \multirow[t]{3}{*}{ A. indica } & 5 & $17.33 \pm 1.45 b$ & $20.00 \pm 2.88 b$ & $13.33 \pm 1.67 b$ & $23.33 \pm 3.01 b$ & $15.00 \pm 2.88 b$ & $8.00 \pm 1.58 b$ & $26.67 \pm 3.82 b$ \\
\hline & 10 & $8.67 \pm 0.8 d$ & $10.00 \pm 1.16 c$ & $6.68 \pm 1.33 c$ & $16.67 \pm 2.41 c$ & $13.33 \pm 1.66 c$ & $6.00 \pm 0.57 c$ & $18.33 \pm 2.66 c$ \\
\hline & 15 & $6.50 \pm 1.68 \mathrm{de}$ & $6.67 \pm 0.33 d$ & $6.68 \pm 1.33 c$ & $6.67 \pm 0.67 e$ & $7.33 \pm 0.33 d$ & $4.67 \pm 0.66 d$ & $10.67 \pm 0.66 d$ \\
\hline \multirow[t]{3}{*}{ J. curcas } & 5 & $12.33 \pm 2.33 c$ & $11.67 \pm 0.67 c$ & $10.00 \pm 2.88 \mathrm{bc}$ & $13.33 \pm 4.09 d$ & $11.67 \pm 2.67 \mathrm{~cd}$ & $8.00 \pm 1.52 b$ & $18.33 \pm 2.66 c$ \\
\hline & 10 & $5.20 \pm 2.16 \mathrm{efg}$ & $4.10 \pm 2.56 \mathrm{def}$ & $3.67 \pm 1.66$ de & $4.67 \pm 1.76 \mathrm{fg}$ & $4.67 \pm 1.67 f$ & $4.00 \pm 1.57 \mathrm{de}$ & $6.00 \pm 2.88 \mathrm{ef}$ \\
\hline & 15 & $4.00 \pm 1.58 \mathrm{~g}$ & $3.67 \pm 0.87 f$ & $3.17 \pm 1.33$ de & $4.00 \pm 1.00 \mathrm{~g}$ & $3.33 \pm 3.88 \mathrm{fg}$ & $3.83 \pm 0.33 \mathrm{e}$ & $4.68 \pm 0.56 f$ \\
\hline \multirow[t]{3}{*}{ Solignum } & 5 & $4.67 \pm 2.82 f$ & $3.94 \pm 0.86 f$ & $4.33 \pm 0.33 d$ & $6.67 \pm 1.67 \mathrm{e}$ & $6.67 \pm 1.66 \mathrm{e}$ & $6.33 \pm 1.33 c$ & $7.00 \pm 1.00 \mathrm{e}$ \\
\hline & 10 & $4.17 \pm 1.67 \mathrm{fg}$ & $3.90 \pm 0.68 f$ & $3.03 \pm 0.67 e$ & $4.67 \pm 0.00 f g$ & $4.00 \pm 1.00 \mathrm{fg}$ & $3.80 \pm 1.02 \mathrm{e}$ & $5.33 \pm 0.66 \mathrm{fg}$ \\
\hline & 15 & $4.07 \pm 0.67 \mathrm{~g}$ & $3.20 \pm 1.57 f$ & $3.00 \pm 0.58 \mathrm{e}$ & $4.33 \pm 0.33 g$ & $3.67 \pm 0.56 \mathrm{~g}$ & $3.67 \pm 0.66 \mathrm{e}$ & $4.60 \pm 0.33 \mathrm{~g}$ \\
\hline Control & 0 & $46.33 \pm 5.64 a$ & $51.67 \pm 3.67 a$ & $45.00 \pm 5.00 \mathrm{a}$ & $50.28 \pm 2.88 a$ & $46.67 \pm 3.33 a$ & $35.00 \pm 5.74 a$ & $65.20 \pm 2.88 a$ \\
\hline$P$ & & $<0.0001$ & $<0.0001$ & $<0.0001$ & $<0.0001$ & $<0.0001$ & $<0.0001$ & $<0.0001$ \\
\hline
\end{tabular}

AT, Antiaria toxicera; GA, Gmelina arborea; BN, Baphia nitida; PB, Parkia biglobosa; PA, Pycnanhus angolensis; TS, Terminalia superba; CP, Ceiba pentandra; Data (\%) were transformed (arcsine) before the analysis of variance; Means ( \pm Standard error) are values of four replicates; Means with the same lower case alphabet in a column are not significantly different from each other (DNMRT: $P>0.05) ;{ }^{b}$ concentration $\left(\mathrm{mL} / 100 \mathrm{~m}^{3}\right.$ of wood surface); $P$, Probability value

Table 6 Pearson's correlation between termite mortality and wood weight loss

\begin{tabular}{llllllll}
\hline & \multicolumn{2}{l}{ Wood weight loss (\%) } \\
\cline { 2 - 7 } & A. toxicera & G. arborea & B. nitida & P. biglobosa & Py. angolensis & T. superba & C. pentandra \\
\hline Mortality (\%) & $-0.948^{* *}$ & $-0.953^{* *}$ & $-0.939^{* *}$ & $-0.935^{* *}$ & $-0.930^{* *}$ & $-0.902^{* *}$ & $-0.909^{* *}$ \\
\hline
\end{tabular}

** Correlation is significant at 0.0001 level (2-tailed)

observed in the study. Stirling et al. (2015) reported similar outcome on Coptotermes formosanus Shiraki mortality and damage caused on Western Red Cedar Heartwood (Thuja plicata L.).

\section{Conclusion}

Both J. curcas oil and A. indica kernel oils showed significant termiticidal activity against $C$. sjostedti. But wood treatment with $J$. curcas kernel oil proved to be more 
efficacious against the insect, and the protection it provided for the seven wood species against $C$. sjostedt $i$ was similar to that of Solignum. We, therefore, recommend the use of J. curcas oil as a potent substitute to synthetic termiticides which has the drawbacks of been toxic to man and the environment. J. curcas kernel oil is relatively cheaper compared to synthetic chemical, and it possesses no risk to humans, livestock and other non-target organisms. However, more research is required to ascertain the persistence of the bioactive compounds J. curcas kernel oil over a long period. This will further enhance the commercial application of these results.

\section{Acknowledgements}

We appreciate the Department of Forestry and Wildlife Resources Management, University of Calabar, Cross River State for the provision of laboratory space and facilities.

\section{Author contributions}

OSI, PMH, and EEE contributed to the conception, experimental work, and interpretation of the analyzed data, writing and reviewing the manuscript. Al authors have read and approved the final manuscript.

\section{Funding}

The work did not receive external funding.

\section{Availability of data and materials}

All data analyzed during this study are included in this published article.

\section{Ethics approval and consent to participate}

Not applicable.

\section{Consent for publication}

Not applicable.

\section{Competing interests}

The authors declare that they have no competing interests.

\section{Author details}

${ }^{1}$ Department of Forestry and Wild life Resources Management, University of Calabar, P.M.B. 1115, Calabar, Nigeria. ${ }^{2}$ Department of Crop and Environmental Protection, Federal University of Agriculture, P.M.B. 2373, Makurdi, Benue State, Nigeria.

Received: 25 September 2020 Accepted: 14 December 2020 Published online: 06 January 2021

\section{References}

Abdullah ZA, Ahmed AZ, Refaat AA (2014) Insecticidal activities of some plant extracts against subterranean termites, Psammotermes hybostoma (Desneux) (Isoptera: Rhinotermitidae). Int J Agric Sci 4:257-260

Abe T, Bingell DE, Higashi M (2000) Termites: evolution, sociality, symbiosis, ecology. Kluwer Academic Publishers, Dordrecht

Addisu S, Mohamed D, Waktole S (2014) Efficacy of botanical extracts against termites, Macrotermes spp., (Isoptera: Termitidae) under laboratory conditions. Int J Agric Res 9:60-73. https://doi.org/10.3923/ijar.2014.60.73

Adebowale KO, Adedire CO (2006) Chemical composition and insecticidal properties of the underutilized Jatropha curcas seed oil. Afr J Biotech 5:901-906

Adolf W, Opferkuch HJ, Hecker E (1984) Irritant phorbol derivatives from four Jatropha species. Phytochemistry 23:129-132

Agboka K, Mawufe AK, Tamò M, Vidal S (2009) Effects of plant extracts and oil emulsions on the maize cob borer Mussidia nigrivenella (Lepidoptera: Pyralidae) in laboratory and field experiments. Int J Trop Insect Sci 29:185-194
Ahmed I, Girma D (2013) Evaluation of some botanicals against termites' damage on hot pepper at Bako, Western Ethiopia. Int J Agric Pol Res 1:48-52

Boateng BA, Kusi F (2008) Toxicity of Jatropha seed oil to Callosobruchus maculatus (Coleoptera: Bruchidae) and its parasitoid, Dinarmus basalis (Hymenoptera: Pteromalidae). J Appl Sci Res 4:945-951

Briffa K (2008) Trends in recent temperature and radial tree growth spaning 2000 years across northwest Eurasia. Philos Trans R Soc B Biol Sci 363(1501):2271-2284

CABI Datasheet (2019). Coptotermes sjostedti. Invasive Species Compendium: Detailed coverage of invasive species threatening livelihoods and the environment worldwide. Available from: https://www.cabi.org/isc/datas heet/15295

Chouvenc T, Li HF, Austin J, Bordereau C, Bourguignon T, Cameron SL, Cancello EM, Constantino R, Costa-Leonardo AM, Eggleton P, Evans TA, Forschler B, Grace JK, Husseneder C, Krecek J, Lee CY, Lee T, Lo N, Messenger M, Su NY (2016) Revisiting Coptotermes (Isoptera: Rhinotermitidae): a global taxonomic road map for species validity and distribution of an economically important subterranean termite genus. Syst Entomol 41(2):299-306. https://doi.org/10.1111/syen.12157

Devappa RK, Angulo-Escalante MA, Makkar HPS, Becker K (2012) Potential of using phorbol esters as an insecticide against Spodoptera frugiperda. Ind Crops Prod 38:50-53

Dowlathabad MR, Sreeyapureddy A, Adhikari A, Bezawada K, Nayakanti D (2010) Pharmaceutical investigation and biopesticidal activity of Jatropha curcas L. seed oil on digestive enzymic profiles of Cnaphalocrocis medinalis (rice leaf folder) and Helicoverpa armigera (cotton boll worm) Int Res J Pharm 1:194-200

Ekhuemelo DO, Musa M (2015) Antitermitic Effect of Moringa oleifera extracts on Gmelina arborea and Ceiba pentandra wood. Nigerian J Agric Food Environ 11(3):55-60

Faruwa FA, Egbuche CT, Umeojiakor AO, Ulocha OB (2015) Investigation into the effectiveness of selected bio-based preservatives on control of termite and fungi of wood in service agriculture, forestry and fisheries. Spec Issue Environ Appl Sci Manag Chang Glob Clim. 4(3-1):59-63. https://doi. org/10.11648/j.aff.s.2015040301.20

Femi-Ola TO, Ajibade VA, Afolabi A (2008) Chemical composition and termicidal properties of Parkia biglobosa (Jacq) Benth. J. Biol. Sci. 8(2):494-497

Finney DJ (1971) Probit analysis. Cambridge University Press, New York

Ganapaty S, Pannakal ST, Serge F, Hartmut L (2004) Antitermitic quinones from Diospyros sylvatica. Phytochemistry 65:1265-1271

Goktas OR, Mammadov E, Duru M, Ozen E, Colak MA, Yilmaz F (2007) Introduction and evaluation of the preservative potentials of the poisonous Sternbergia candidum extracts. Afr J Biotechnol 6:982-986

Grace JK, Yates JR (2008) Behavioural effects of a neem insecticide on Coptotermes formosanus (Isoptera: Rhinotermitidae). Trop Pest Manag 38(2):176-180. https://doi.org/10.1080/09670879209371679

Guo L, Quicili DR, Chase J, Blomquist GJ (1991) Gut tract microorganisms supply the precursors for methyl-branched hydrocarbon biosynthesis in the termite, Zootermopsis nevadensis. Insect Biochem 21:327-333

Gérard J, Paradis S, Thibaut B (2019) Survey on the chemical composition of several tropical wood species. Bois et Forêts des Tropiques 342:79-91. https://doi.org/10.19182/bft2019.342.a31809

Harris WV (1966) On the genus Coptotermes in Africa (Isoptera: Rhinotermitidae). R Entomol Soc Lond 35:161-171

Isman M, Koul O, Arnason J, Stewart J, Salloum G (1991) Developing a neembased insecticide for Canada. Memoirs Entomol Soc Can 123:39-46. https ://doi.org/10.4039/entm123159039-1

Jambere B, Obeng-Ofori D, Hasanali A (1995) Product derived from the leave of Ocimium mkilimandschanu (Labiatae) as post-harvest grain protectants against the infestation of three grain stored products insect pests. Bull Entomol Res 85:361-367

Johnson RA, Wood TG (1980) Termites of the arid zones of Africa and the Arabian Peninsula. Sociobiology 5:279-293

Kshirsagar RV (2010) Insecticidal activity of Jatropha seed oil against Callosobruchus maculatus (Fabricius) infesting Phaseolus aconitifolius Jacq. Bioscan 5:415-418

Kuriachan I, Gold RE (1998) Evaluation of the ability of Reticulitermes flavipus Kollar, a subterranean termite (Isoptera: Rhinotrmitideae) to differentiate between termiticide treated and untreated soils in laboratory tests. Sociobiology 32:151-166 
Kuswanto E, Ahmad I, Dungani R (2015) Threat of Subterranean termites attack in the Asian Countries and their control: a review. Asian J Appl Sci 8:227-239. https://doi.org/10.3923/ajaps.2015.227.239

Li J, Yan F, Wu FH, Yue BS, Chen F (2004) Insecticidal activity of extracts from Jatropha curcas seed against Lipaphis erysimi. Acta Phytophylacica Sinica 31:289-293

Logan JWM, Cowie RH, Wood TG (1990) Termite (Isoptera) control in agriculture and forestry by non-chemical methods: a review. Bull Entomol Res 80:309-330

Loko YLE, Orobiyi A, Toffa J, Agre P, Tamo M, Yves Roisin Y (2019) Termites (Blattodea: Termitidae) diversity and assemblages in different yam fields habitats in central Benin, Faunistic Entomology. https://popups.ulieg e.be:443/2030-6318/index.php?id=4621

Myles TG (1998) Phylogeny and taxonomy of the Isoptera. In: Schwarz MP, Hogendoorn K (eds) Social insects at the turn of the millennium. Flinders University Press, Adelaide, Australia, p 334

Nabil AEA, Yasser AMK (2012) Jatropha curcas oil as insecticide and germination promoter. J Appl Sci Res 8:668-675

Ndiaye AB, Njie E, Paul A, Correa PA (2019) Termites (Blattodea Latreille 1810, Termitoidae Latreille 1802) of Abuko Nature Reserve, Nyambai Forest Park and Tanji Bird Reserve (The Gambia). Insects. 15:17. https://doi. org/10.3390/insects10050122

Odelson DA, Breznak JA (1983) Volatile fatty acid production by the hind gut microbiota of xylophagus termites. Appl Environ Microbiol 45:1602-1613

Okweche SI, Hilili PM, Ita PB (2015) Comparative Efficacy of some insecticidal plant materials against dry wood termite (Cryptotermes cavifrons BANKS (Insecta: Isoptera: Kalotermitidae) Infestation. Greener J Agric Sci 5(6):210-216

Osipitan AA, Oseyemi AE (2012) Evaluation of the bio-insecticidal potential of some tropical plant extracts against termite (Termitidae:Isoptera) in Ogun State, Nigeria. J Entomol 9:257-265. https://doi.org/10.3923/ je.2012.257.265

Osipitan AA, Owoseni JA, Odeyemi IS, Somade AA (2010) Assessment of extracts from some tropical plants in the management of termite (Termitidae: Isoptera) in Ogun State. Nigeria, Arch Phytopathol Plant Prot 43(10):962-971

Oskoueian E, Abdullah N, Ahmad S, Saad WZ, Omar AR, Ho YW (2011) Bioactive compounds and biological activities of Jatropha curcas L. kernel meal extract. Int J Mol Sci 12(9):5955-5970. https://doi.org/10.3390/ijms120959 55

Padi B, Adu-Acheampong R, Nkansah A (1999) Preliminary results on the laboratory and field test on Neem Azal, for cocoa capsid control in Ghana, in Proceedings workshop on commercialization of neem tree productsin Ghana. October 19-21, 52-54.

Ratnadass A, Cissé B, Diarra A, Mengual L, Taneja SL, Thiéro CAT (1997) Perspectives de gestion bio intensive des foreurs des tiges de sorgho en Afrique de l'Ouest. Insect Sci Appl 17:227-233

Ratnadass A, Togola M, Cissé B, Vassal JM (2009) Potential of sorghum and physic nut (Jatropha curcas) for management of plant bugs (Hemiptera: Miridae) and cotton bollworm (Helicoverpa armigera) on cotton in an assisted trap-cropping strategy. J SAT Agric Res 7:1-7

Ratnadass A, Wink M (2012) The phorbol ester fraction from Jatropha curcas seed oil: potential and limits for crop protection against insect pests. Int J Mol Sci 13(12):16157-16171. https://doi.org/10.3390/ijms131216157

Ross RJ (2010) Wood handbook: wood as an engineering material. Centennial ed. General technical report FPL ; GTR-190. Madison, WI : U.S. Dept. of
Agriculture, Forest Service, Forest Products Laboratory: 1 v. https://www. fs.usda.gov/treesearch/pubs/37440

Rust MK, Su NY (2012) Managing social insects of urban importance. Annu Rev Entomol 57:355-375

SAS (2009). Statistical Analysis System SAS/STAT User's Guide Version 9.2 SAS Institute. Inc. Cary. NC.

Samuel JR (2004) The Mechanical Properties of Wood; Including a Discussion of the Factors Affecting the Mechanical Properties and Method of Timber Testing. Yale University. http://www.cwru.edu/UL/preserve/general.htm

Sauerwein M, Sporer F, Wink M (1993) Insect-toxicity of phorbol esters from Jatropha curcas seed oil. Planta Med 59:686

Sbeghen AC, Dalfovo V, Serafini LA, Barros NM (2002) Repellence and toxicity of basil, citronella, ho-sho and rosemary oils for the control of the termite Cryptotermes brevis (Isoptera: Kalotermitidae). Sociobiology 40:585-594

Scheffrahn RH, Krecek J, Maharajh B, Su NY, Chase JA, Mangold JR, Szalanski A L, Austin JW, Nixon J (2004) Establishment of the African termite, Coptotermes sjostedti (Isoptera: Rhinotermitidae), on the Island of Guadeloupe, French West Indies. Ann Entomol Soc Am 97:872-876

Sen S (2001) Determination of effect of some plant phenols on wood protection. Ph.D. Thesis, University of Karadmas, Institute of Science, Zonguldak Turkey, pp 295

Singh N, Sushilkumar A (2008) Anti termite activity of Jatropha curcas Linn. Biochemicals. J Appl Sci Environ Manag 12:67-69

Singha D, Singha B, Dutta B (2012) Potential of some plant extracts to control termite pest of tea (Camellia sinensis L. (O) Kuntze) plantations of Barak Valley, Assam India. Int J Tea Sci 8(4):3-9

Singha D, Singha B, Dutta BK (2013) Potential of some plant extracts to control termite pest of tea (Camellia sinensis L. (O) Kuntze) plantations of Barak Valley, Assam India. Int J Tea Sci 8:3-9

Sohail A, Asif N, Shakil F (2005) Comparative efficacy of botanicals and insecticides on termites in sugarcane at Faisalabad. Pak Entomol 27(2):11-14

Stirling R, Paul I, Morris J, Kenneth G (2015) Prediction of the decay and termite resistance of Western Red Cedar Heartwood. Forest Prod J 65(3-4):84-92. https://doi.org/10.13073/FPJ-D-14-00056

Su NY (2002) Novel technologies for subterranean termite control. Sociobiology 40:95-102

Su NY, Scheffrahn RH (1990) Economically important termites in the United States and their control. Sociobiology 17:77-92

Upadhyay RK (2013) Effects of plant latex based anti-termite formulations on Indian white termite Odontotermes obesus (Isoptera: Odontotermitidae) in sub-tropical high infestation areas. Open J Anim Sci 3:281-294

Watanabe D, Gotoh H, Miura T, Maekawa K (2014) Social interactions affecting caste development through physiological actions in termites. Front Physiol 5:127. https://doi.org/10.3389/fphys.2014.00127

Wink M, Koschmieder C, Sauerweien M, Sporer F (1997) Phorbol esters of J. curcas-Biological activities and potential applications. http://www.uniheidelberg.de/institute/fak14/ipmb/phazb/pubwink/1997/24.\%20199 7.pdf. Accessed 23 November 2019

Wood TG, Johnson RA, Ohiagu CE (1980) Termite damage and crop loss studies in Nigeria: a review of termite (Isoptera) damage, loss in yield and termite Microtermes) abundance at Mokwa. Trop Pest Manag 26:241-253

\section{Publisher's Note}

Springer Nature remains neutral with regard to jurisdictional claims in published maps and institutional affiliations. 